\title{
CLUSTER ANALYSIS OF FINANCIAL BEHAVIORS AND PREFERENCES AMONG THE BOTTOM OF THE PYRAMID GROUP
}

\author{
Dewi Saraswati ${ }^{1 *}$, Dian Kusumaningrum ${ }^{2}$ \\ ${ }^{1}$ School of Business and Economics, Prasetiya Mulya University \\ ${ }^{2}$ School of Applied STEM, Prasetiya Mulya University \\ "Corresponding author email: dewi.saraswati@pmbs.ac.id
}

\begin{abstract}
This study investigates the financial behavior and preferences of the bottom of the pyramid (BOP) group, and thus, contributes to the financial inclusion demand-side literature. A survey of 100 households was conducted. A cluster analysis was used to analyze the data and portray the characteristics of the BOP. Further analysis was conducted using chi-square and ANOVA tests. The results reveal three sub-groups within the BOP which consists of the very low, low, and medium. Financial behaviors are found to be indifferent among the sub-groups, except for savings allocations and financial planning. Households with a better economic condition are found to have a higher attention to use banking services. The financial literacy category indicates different attitudes in conducting long-term financial planning and service preferences. This result implies that financial literacy and adequate financial products are beneficial towards the financial inclusion of the BOP group.
\end{abstract}

Keywords: Financial inclusion, financial behavior, financial preferences, financial literacy, cluster analysis

\section{Introduction}

The Bank of Indonesia defines the bottom of the pyramid (BOP) as the group of people with low and irregular incomes. These people usually live in remote areas. Disabled people, workers who do not have legal identity documents, and marginalized communities are also considered part of the BOP (Bank of Indonesia, n.d.). BOP groups generally earn income from the informal sector, which usually means their income is non-permanent, irregular, and uncertain. In addition, the income value differs over time or with the seasons (Kilara \& Rhyne, 2014). In this paper, BOP stands for the BOP society.

Savings and borrowings are basic financial activities that are considered common practices in Indonesia; $62 \%$ of adults have allocated money for savings and 55\% of adults have borrowed money in the past year (Demirgüç-Kunt, Klapper, Singer, Ansar, \& Hess, 2018). Common financial services are offered by formal financial institutions (i.e., bank). However, BOP groups commonly obtain financial services from the informal sector (e.g., family and friends, private informal lenders, savings clubs). Informal lenders are inadequate, risky, costly, and uncertain (Kilara \& Rhyne, 2014).

According to the World Bank Global Findex survey report, in 2017, 48.86\% of Indonesian adults accessed formal financial services, while only $36 \%$ of Indonesia's poorest people had access to formal accounts from financial institutions. In global economies, poorer adults are consistently less likely to have a formal account than a wealthier adult. Among adults in the richest $60 \%$ of households within economies, $74 \%$ have an account. In contrast, only $61 \%$ among those in the poorest $40 \%$ of households have an account (Demirgüç-Kunt et al., 2018). Consequently, the BOP society is believed to be the largest group exposed to the unfavorable consequences of low financial inclusion (e.g., transaction risks, lack of liquidity management under economic shocks) (Lusardi, 2010; Gross, Hogarth, \& Schmeiser, 2012).

Furthermore, there is a significant correlation between higher financial inclusion and lower poverty (Anwar, Uppun, \& Reviani, 2016; Park \& Mercado Jr., 2015). Higher financial inclusion in both studies is associated with broader access to formal financial services. This enables smooth consumption and people engaging in productive activities. This also significantly reduces income inequality (Park \& Mercado, Jr., 2015).

Boukhatem (2016) agreed that interactions between higher financial inclusions through formal borrowing and an extended number of financial institutions will benefit poor people more if they increase the amount of money they save and earn money on their deposits. This is expected to reduce the poverty gap.

High financial inclusion refers to a condition where effective, appropriate, and affordable financial services are broadly accessed by individuals, households and businesses (Kilara \& Rhyne, 2014). The international society believes that high financial inclusion is a critical contributor towards inclusive econo- 
mic growth, poverty reductions, and reducing the socio-economic gap.

Financial services are interlinked with a country's financial stability, as it is a contributor to global financial stability (World Bank, 2012). Consequently, the World Bank initiative for Universal Financial Access 2020 (UFA 2020) focuses on 25 priority countries, where $73 \%$ of the financially excluded society live. Indonesia is included in the priority group and contributes $5.6 \%$ to financially excluded people globally (World Bank, 2017). In 2016, the Indonesian Government kicked off the country financial inclusion strategy called the National Strategy of Financial Inclusion (SNKI), through Indonesia Presidential Decree No. 82 Year 2016, and aimed to reach 75\% financial inclusion at the country level by 2019 .

The decision to use or not use financial services is part of a financial decision making process. The financial decision making process varies across generations, literacy levels, life cycle models, and family socioeconomic status (Brounen, Koedijk, \& Pownall, 2016). The household financial decision making process involves the correlation of perception, literacy level, optimism, and beliefs in financial services (Anderson, Baker, \& Robinson, 2017). Therefore, to increase our understanding of financial inclusion, it is important to analyze demand-side data. Focus should be placed on the characteristics of the financially excluded group's behavior in making a financial decision and preferences across generations, literacy levels, and demographic characteristics (e.g., socioeconomic status).

Financial inclusion studies have been disseminated by both global (i.e., World Bank) and local organizations within countries. This has included Indonesia since 2014. Most studies only provide general information about the country perspective and the demographic groups. Financial inclusion research highlights financial behaviors, literacy level, and BOP preferences. These variables are usually analyzed broadly, without considering the specific characteristics in a certain BOP group.

Indonesia is a country that still has large diversity within the BOP. Therefore, analyzing data more specifically based on certain BOP groups would be useful. It would allow the researcher to set specific recommendations that will be used to provide guidance to policy makers and strategies for financial regulators. The financial industry will also obtain information on performing interventions to assist the financial services user meet the needs, and increase the awareness, of the financially excluded groups, as a potential user (World Bank, 2012).
A two-step cluster analysis is conducted to identify specific characteristics of the BOP groups. Furthermore, we analyze the specific behaviors and preferences of the BOP in conducting their financial activity, based on the cluster characteristics and financial literacy. Therefore, we measure the actual financial literacy and the gap or bias between the actual and perceived financial literacy. Furthermore, the comparison tests are conducted based on the Chisquare and ANOVA tests to further analyze the different behaviors among groups and financial literacy categories.

The World Bank (2014) defines financial inclusion as the percentage of individual adults above 15 years old who have access to formal financial services. Formal financial service types include payments, savings, loans, insurance, pension plans, and investments. Formal financial services are considered sustainable, both from the financial service provider and regulatory standpoint. Broader access to formal financial services will support the society to survive in an economic shock wave. Therefore, financial inclusion is interlinked with country financial stability, which, in turn, supports global financial stability (World Bank, 2012).

Financial inclusion is related to the financial behavior of people. Moreover, it is related to the people, methods, and times the financial activities are executed. Niculescu-Aron and Mihaescu (2012) proposed that, in a country with favorable economic progress, the encouraging factors that motivate individuals to have savings is the excess income derived from income increases, people's expectations and belief in the savings product's gain, fiscal policy, and economic outlook. The economic shock indicates behavioral savings changes, but differs among countries. Niculescu-Aron and Mihaescu (2012) also suggested national specific characteristics and behavioral parameters.

There are some studies about financial behavior and its correlation with financial literacy. Based on evidence in Indonesia and India, a financial literacy program has a modest effect on financial inclusion for the uneducated and financially illiterate households. It is not as effective as small subsidy payments (Cole, Sampson, \& Zia, 2009).

The latest cross country study confirmed that financial literacy has a positive and significant relationship with the use of financial services (Grohmann, Klühs, \& Menkhoff, 2018). Basic financial services available for customers include a savings account, payments, and transfers. More sophisticated financial products include credit cards, insurance, and pension plans. At the country level, financial literacy is sup- 
plementary to increase financial inclusion in the country, with a lack of financial infrastructure and depth. Good financial literacy contributes to good financial decision making and financial inclusions.

This study supports the previous research results in Allgood and Walstad (2012), who indicated that financial literacy makes a substantial contribution to explain financial behaviors. The effects were stronger with topics related to more sophisticated financial products (e.g., investments, insurance). People with a low education level are generally not very financially literate. This results in a low financial activity output, especially on pension plan savings. As a result, these groups of people are more exposed to the negative impact of financial shocks and future uncertainty in the future.

Brounen et al. (2016) found a linkage between savings behavior and financial literacy. The savings intention varies across generations and was mostly conducted by generations born before 1980 . The young generation, with a prospering family background, have higher intentions to save money later in life. On the other hand, savings intentions are stronger among younger households with high levels of financial literacy.

Kiliyanni and Sivaraman (2016) found that education, the discipline of study, occupation, work experience, income, and parents' education and occupations influence financial literacy. Nidar and Bestari (2012) also found that the family, especially the parents, remain the most important source of knowledge about managing personal finances. Therefore, parents play an important role as a role model for the younger generation (university students), in terms of personal financial management.

People tend to have biases and overconfidence regarding their financial literacy levels. Anderson et al. (2017) discovered that overconfidence, as a result of perceived financial literacy, significantly influences individuals to participate in financial decisions, especially among people with low financial knowledge. They tend to have mistaken beliefs about financial products and less enthusiasm about receiving financial advice.

Mindra, Moya, Zuze, and Kodongo (2017) stated that there is a strong positive and significant relationship between financial self-efficacy and financial inclusion. Financial self-efficacy is the ability to activate the actual confidence that individual financial consumers require using the financial services available to them to improve lives. Anderson et al. (2017) found that the self-perception of financial literacy, precautionary savings, and retirement planning are positively correlated.
Danella, Rahadi, and Helmi (2017) suggested that financial education and the preliminary knowledge of financial products and services will influence the level of financial literacy. On the other hand, wealth background, access to financial products and services, and socio-demographics act as moderating factors which indirectly influence the household wealth accumulation process.

Based on these theoretical backgrounds, the first hypothesis tested as research attention is there are subgroups with dissimilar characteristics within BOP people in Indonesia. This hypothesis was developed because of the Bank of Indonesia's BOP definition. They consider some groups, including people with low and irregular incomes, people who usually live in remote areas, disabled people, workers who do not have legal identity documents, and marginalized communities (Bank of Indonesia, n.d.), as BOP. Adding to the Bank of Indonesia's BOP definition, Kilara and Rhyne (2014) include irregular and uncertain income as BOP society characteristics. Thus, we formulate the following research hypothesis:

$H_{l}$ : The BOP society can be divided into more than one subgroup with different characteristics.

Household characteristics influence financial literacy (Nidar \& Bestari, 2012; Kiliyanni \& Sivaraman, 2016). Households with a better education level generally provide a better source of financial literacy (Nidar \& Bestari, 2012; Allgood \& Walstad, 2012). Moreover, wealth background leads to higher opportunity to access education and financial services. Thus, households with different education, occupation, and income tend to have different financial literacy level. As a result, we develop the following hypothesis:

$H_{2}$ : There is at least one sub-group or cluster of BOP society that has a different financial literacy level.

Various studies have proven that there is a relationship between financial behavior and its correlation with financial literacy and household sociodemographic characteristics. Economic condition and excess income motivate individual to save (Niculescu-Aron \& Mihaescu, 2012). Motivation and timeline execution are found vary across generation with the same economic level (Brounen et al., 2016). The different consumer behavior across generation influence the lifestyle hence priorities and the purpose of savings. Moreover, financial literacy can stimulate self-efficacy to use a financial service. Consequently, encourages good financial decision and more active 
financial activities (Allgood \& Walstad, 2012; Mindra et al., 2017; Grohmann et al., 2018). Thus, we formulate two hypotheses $\left(H_{3}\right.$ and $\left.H_{4}\right)$ regarding the relationship between household socio-demographic characteristics and financial literacy on savings behavior. Here, savings represents basic financial services.

$H_{3}$ : There is a relationship between savings behavior and the BOP sub-groups.

$H_{4}$ : There is a relationship between savings behavior and the financial literacy category.

Financial knowledge is required to conduct financial planning. Financial planning considers the purpose of life, the productive period to earn income, available resource, and preliminary knowledge regarding financial products.

Financial literacy effects are vigorous and significant regarding topics of more sophisticated financial products (e.g., investments, insurance) used in financial planning (Allgood \& Walstad, 2012). We then formulate a relationship between household demographic characteristics and financial literacy towards financial planning behavior in $H_{5} \& H_{6}$. Here, financial planning represents the more sophisticated financial behaviors, such as investment, insurance, and pension plan.

$H_{5}$ : There is a relationship between financial planning and the BOP sub-groups.

$H_{6}$ : There is a relationship between financial planning behavior and the financial literacy category.

Interpretations about preferences depend on the study's approach. From a marketing perspective, preferences refer to the likelihood to select an option over the alternatives offered. In an economic study, preferences are defined as individual tastes, indicated by the utility of various products or services (Sowunmi, Omigie, \& Daniel, 2014; Thiyagaraj, 2015).

Preferences are an individual's attitudes towards a set of entities that stimulate individual behavior in the decision making process (Lichtenstein \& Slovic, 2006). This process involves collecting relevant information about the products' attributes and evaluating the information before assigning a value in relation to choosing between alternatives (Hawkins \& Mothersbaugh, 2010).

Financial inclusion is closely related to people's decisions in using financial services from formal financial institutions, when compared to the other alternatives. In this way, we can better understand people's preferences about financial services alternatives. This information assists in determining the success of financial inclusion.
Considering these fundamentals and references regarding financial preferences, we formulated $H_{7}$ and $H_{8}$ :

$H_{7}$ : There is a relationship between financial preferences and BOP groups.

$H_{8}$ : There is a relationship between financial preferences and the financial literacy category.

Figure 1 illustrates the conceptual framework of the data processing procedure and the analysis.

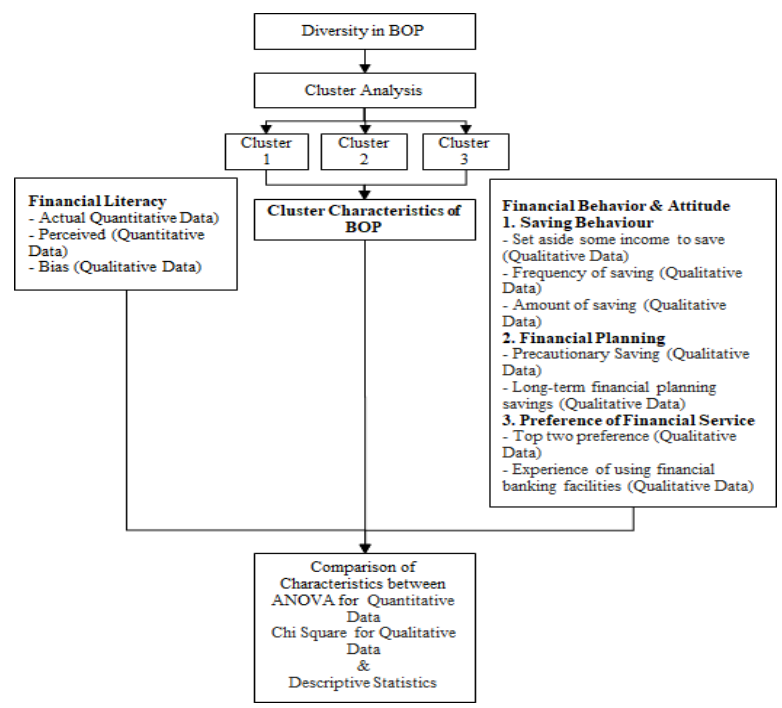

Figure 1. Conceptual framework of data processing and analysis

\section{Research Method}

\section{Survey and Sampling Method}

Data was collected with a paper survey of BOP respondents living in the remote areas of the Bogor Regency, Indonesia. Surveys are commonly conducted by researchers in the field of sociology, business, politics, government, and education.

The quality and quantity of the sample greatly determines the quality of the results. The sample characteristics of a population need to be generalized as a result of the research. The sample size is strongly influenced by the variance in the population, the precision desired in the study, the plans of the analysis, and the limitations of human resources (e.g., costs, time).

Israel (1992) and Lind, Marchal, and Wathen (2015) stated a general formula that can be used to determine the sample size:

$$
n=\left(Z^{2} \sigma^{2}\right) / e^{2}
$$

where $n$ is the required sample size for the desired level of precision, $e$ is the effect size, $Z$ is the degree of confidence, and $\sigma$ is the standard deviation of a 
population. A random sample from a population is defined by a standard deviation of 100 , where the desired confidence level is 1.96 (significance level of 0.05 ) and the size effect is 20. Consequently, the required sample size for this study is $[100(1.96) / 20)]$ $2=96$.

Systematic sampling was used in this investigation, because it is a useful sampling option for sampling from a very large population. Systematic sampling is a method where only the first element of the sample is randomly chosen, while the next elements are systematically selected according to a particular pattern. The sampling process involves each sequence of " $K$ " being obtained from a randomly selected starting point, where:

$$
K=N / n
$$

$N$ is the number of people in the population, while $\mathrm{n}$ is the number of samples. The primary advantage of using the systematic random sampling method is that planning and use are easy to organize. In addition, the samples will be spread throughout the population

Aside from considering cost and location constraints, Bogor Regency was chosen as the study area because: (1) West Java is the province with the third largest number of poor people in Indonesia and Bogor Regency has the highest contribution toward the total poor population (11.48\%) (Badan Pusat Statistik, 2019a), (2) Bogor Regency has the largest number of people aged 15 years and older in West Java (Badan Pusat Statistik, 2019b), who are considered the target of the financial inclusion strategy, (3) The Indonesian Financial Service Authority (OJK) reported that West Java has the lowest financial inclusion and financial literacy index, when compared to the average financial inclusion and literacy index of five provinces in Java (Otoritas Jasa Keuangan, 2016).

Three districts in the Bogor Regency were chosen. Each is expected to capture the characteristics of different types of respondents, representing the target population of the survey. The Cibinong Sub-district represents the industrial laborers area. The sub-districts of Dramaga and Cibungbulang represent agriculture areas. For each sub-district, four villages were randomly chosen. The number of samples in each village ranged from 5-20.

\section{Questionnaire: Design, Reliability \& Validity Test, and the Quality Control}

The questionnaire was divided into four parts. Part One explores the respondent's personal demographic information (e.g., age, gender, education, occupation). Part Two to Four include the variable indicators used to grasp: (1) Financial Behavior, (2) Financial Literacy, and (3) Financial Preferences. The questions were based on multiple response questions and multiple-choice options, which were dependent on the context of the questions.

A pre-test was conducted to test and evaluate the questionnaire based on: (1) the content validity with rational judgment, and (2) calculating the reliability index based on the Cronbach Alpha tests. The validity and reliability test of the instrument was conducted. The results reveal that some items in the survey instrument had fairly low reliability. Therefore, the results of the pre-survey, validity test and reliability of this instrument was useful in refining the research instrument to be used in the data collection process and developing the final version of the survey instrument.

Aside from the reliability and validity tests, the quality control process on the questionnaire was based on the call back activities to respondents to verify the recorded data in the database. Callbacks were randomly conducted to $25 \%$ of the respondents. The samples were distributed proportionally and performed for all surveyors.

There is a large amount of diversity within the BOP. Therefore, analyzing certain BOP groups would be useful to set specific recommendations. Consequently, a cluster analysis was conducted to group the BOP in the first stage of the analysis.

Descriptive statistics on the clusters and the characteristics of the BOP were used to describe the basic features of the data in a study. They provide simple summaries about the sample and the measures. Together with a simple graphical analysis, they form the basis of virtually every quantitative analysis.

Chi-square and ANOVA tests were used to analyze the different characteristics of the BOP, based on the BOP groups and financial literacy. ANOVA tests were used for the quantitative actual and perceived financial literacy data.

\section{Two-Step Cluster}

Having both continuous and categorical data led to the selection of a Two-Step Clustering procedure to analyze the nature of the groups and the sample's characteristics. Two-Step Clustering is a clustering method that is capable of handling continuous and categorical variables or attributes. It requires only one data pass in the procedure. The first step of the procedure is conduct pre-cluster of the records into many small sub-clusters. Next, the sub-clusters from the pre-cluster step then grouped into the desired number of clusters. If the desired number of clusters is unknown, the Two-Step Cluster Component will automatically determine the proper number of clusters. 
The results gathered from running a simulation are consistently accurate and scalable in performance. By clustering, we can group the data so that the records within a group are similar (SPSS, n.d.).

\section{Chi-Square and ANOVA}

The Chi-Square statistic is commonly used for testing relationships between categorical variables, especially in cross tabulations. A cross-tabulation presents the distributions of two categorical variables simultaneously, with the intersections of the categories of the variables appearing in the cells of the table. The null hypothesis of the Chi-Square test is that no relationship exists on the categorical variables in the population; they are independent. The calculation of the Chi-Square statistic is quite straightforward and intuitive:

$$
\chi^{2}=\sum \frac{\left(f_{0}-f_{e}\right)^{2}}{f_{e}}
$$

where $f_{o}$ is the observed frequency (the observed counts in the cells) and $f_{e}$ is the expected frequency if no relationship exists between the variables. Calculating the Chi-Square statistic and comparing it with the critical value from the Chi-Square distribution allows the researcher to assess whether the observed cell counts are significantly different from the expected cell counts.

The Analysis of Variance (ANOVA) is a collection of statistical models and their associated procedures (e.g., "variation" among and between groups) used to analyze the differences between the group means. In its simplest form, ANOVA provides a statistical test of whether the means of several groups are equal, and therefore, generalizes the $t$-test to more than two groups. ANOVA is useful for comparing (testing) three or more means (groups or variables) for statistical significance. It is conceptually similar to multiple two-sample $t$-test, but is more conservative (results in fewer Type I errors) (Diez, Barr, \& Cetinkaya-Rundel, 2012).

The F-test is used for comparing the factors of the total deviation. For example, in a one-way, or single-factor ANOVA, statistical significance is tested for by comparing the $F$-test statistic:

$$
F=\frac{M S_{\text {Treatments }}}{M S_{\text {Error }}}=\frac{S S_{\text {Treatments }} /(I-1)}{S S_{\text {Error }} /\left(n_{T}-I\right)}
$$

where, $M S$ is the mean square, $I$ is the number of treatments and $n_{T}$ is the total number of cases to the $F$ distribution with $\left(I-1, n_{T}-I\right)$ degrees of freedom.

To reject the Null Hypothesis for either of the tests, we will compare the observed value of the $F$ or Chi-square with the critical value of the $F$ or Chi- square. If the observed value is greater than or equal to the critical values, the null hypothesis is rejected.

We can also compare the p-value. Here, the computer calculates the probability of a value of $F$ or Chi-Square greater than or equal to the observed value. The null hypothesis is rejected if this probability is less than or equal to the significance level $(\alpha)$.

\section{Result and Discussion}

We will now describe the characteristics of the BOP clusters or groups based on the Two-Step Cluster analysis. Next, we will elaborate on the savings behavior of the BOP, as well as the comparisons among the groups that would be followed by a literacy score (i.e., actual, perceived, and bias). The preferences of the BOP's financial services and the experience of using banking will also be discussed in the next section. This will be followed by BOP comparisons. In the last section, a comparison between behaviors and preferences, based on a literacy score (i.e., actual, perceived, bias) will be conducted.

\section{Cluster Characteristics}

The variables used for the two-step cluster approach include electrical power installed, home ownership status, age, last formal education, average electricity expenses, and the occupation of the household head. These variables were chosen because they capture the diversity of the sample.

Electricity expenses were used as an indicator of income, because in Indonesia, people are very reluctant to declare their income levels. Therefore, high electricity expenses will indicate a higher income. This assumption is in line with Nazer \& Handra (2016), who confirmed that household income is the most significant determinant of energy consumption in urban areas.

The two-step cluster analysis was used to divide the BOP group into three clusters. Table 1 illustrates the detailed characteristics of these clusters. The first cluster is a very low-income group. Groups of people within this first cluster live in their own house, but install low voltage electricity and have low electricity consumption (average electricity expense IDR80, 424). They are from the baby boomers' generation (average age 47 years old) and have a low education. Most of these people are farmers. This group is considered a very reluctant or very low group. The second cluster (the low group), only differs from the first by the average electricity bill. It is higher than that of the very low cluster (average electricity expense IDR181,133). They are also from the baby 
boomers' generation (average age 44 years old). They have a higher income than the first cluster.

The third cluster (medium group) is different in every way to the first and second clusters. People in this group have higher voltage electricity ( 900 Volts), do not have their own house, and are, on average, younger (i.e., average age 30 years old (millennials)). They also have a higher education (graduated high school) and a higher electricity bill (average IDR 232,000 ), indicating a higher income. The majority of people in this group are entrepreneurs.

Clustering the sample was a crucial part of this investigation, because Brounen et al. (2016), in Holland, indicated that financial decision behaviors differ across generations and family socioeconomic status. Having further knowledge of this information in Indonesia will be useful for financial regulators and the financial industry in Indonesia. In this way, they will gain a better understanding about BOP group specifics to develop more effective policies and strategies to increase financial inclusion.

\section{Savings Behavior}

Overall, $68.75 \%$ of the sample set aside some income to save, which is considered high. As for the frequency of saving, slightly more people set aside their income for savings regularly $(56.16 \%)$ and set aside more than $5 \%$ of their income $(56.3 \%)$. The most important reason for people to save income is for fundamental needs (e.g., fulfilling basic needs, survival, education, buying a vehicle, insurance, investments, and holidays). Less than $10 \%$ of the respondents chose these options.

Detailed results of the cross tabulations and ChiSquare savings behavior can be seen in Figure 2 . Based on the Chi-square tests at alpha $15 \%$, the financial behavior of these groups is the same. It is based on the behavior of saving money and the frequency of saving. All groups tend to save income. More people save on a regular basis, especially in the very low and medium groups. As for the percentage of savings, it is significantly different. The very low group has a higher percentage of savings $(>5 \%$ of income), the medium group has a balance between savings below and above 5\% of their income, while the lower groups have a lower percentage of savings ( $<5 \%$ of income).

The very low cluster shows the tendency of a higher willingness to save. This group has the lowest income. Hence, the people in this group are willing to sacrifice more on the consumption allocation. The oldest age group shows the tendency to be more disciplined and committed to savings. They allocate a higher percentage of income to savings, concurring with the results in Brounen et al. (2016).

The Indonesian's poorest people, the BOP society, is the largest group exposed to the unfavorable consequence of low financial inclusion. One of the unfavorable consequences is the lack of liquidity management under economic shocks (Lusardi, 2010; Gross et al., 2012). To manage liquidity under an economic shock involves having precautionary savings and long-term financial planning. The purposes of the emergency fund are to cover at least three months of income, due to an economic crisis, healthcare service needs, losing a job, and other emergency conditions.

This study finds that $51.58 \%$ of BOP people have precautionary savings, while only $26.31 \%$ conduct long-term financial planning (Figure 3). This phenomenon differs between groups. Cluster 1 , as the least prosperous (most reluctant) and oldest age group, illustrates the highest action to set aside an emergency fund. The very low group (Cluster 1) is followed by the medium group and the low group. As for long-term financial planning, represented by having a pension plan or not, it was determined that as the economic level increases, more people become aware of long-term financial planning or pension plans.

The most reluctant group tends to save more emergency funds, vice versa with long-term financial planning. The most reluctant group has a very low income and a higher average age. Therefore, there is a tendency to have a higher awareness and higher responsibility of the importance to save emergency funds. As people's age increases, they realize that they are faced with shorter productive periods of time. They are also aware of health declines, forcing them to set aside more funds to savings, rather than spending it on tertiary needs.

For long-term financial planning, people need more income and awareness. We are analyzing pension plans which need a higher level of financial commitment. The type of occupation and the higher level of education also influences the awareness of having long-term financial planning (pension plan) in place. This is illustrated in our studies. People in Cluster 3 (medium), with entrepreneurs as occupations and a higher education level, have a significantly higher awareness of long-term financial planning (pension plan) as a savings purpose. People working as a farmer and having a lower education level do not have this awareness. 


\section{Financial Literacy}

Financial literacy is the level of knowledge, skills, and societal beliefs related financial institutions and products and services, as outlined in the index size parameters (Financial Services Authority, 2013). Financial literacy helps in providing an understanding of managing finances and opportunities to achieve a more prosperous life in the future. We measured financial literacy by using three conceptual questions about interest compounding, inflation and risk diversification alternative instruments. These questions were based on Lusardi and Mitchell's study (2014). We added the concepts of mortgage installment and bond pricing.

The financial literacy measurement results are illustrated in Figure 4. Based on the proportion of correct responses of the five areas of literacy measured, we found that interest and compounding is the best understood concept (34\% correct responses) by the respondents. This was followed by inflation (18\%) and mortgage \& installment (16\%). The concept of risk \& diversification and bond pricing only received $<5 \%$ correct answers. This may occur as the implication of low BOP group engagement to investments.

This study builds upon Allgood and Walstad's (2012) study results, which stated that the perceived financial literacy arises from financial decision outcomes related to investments. We not only measured the actual level of literacy, but also the perceived level of literacy, which is the self-evaluation of the level of literacy. The difference between the actual and perceived levels of literacy will be calculated as the bias literacy.

Table 1

\section{Two Step Cluster Identification}

\begin{tabular}{|c|c|c|}
\hline $\begin{array}{c}\text { Cluster } 1 \\
\text { Very Low }(33 \%) \\
\end{array}$ & $\begin{array}{c}\text { Cluster } 2 \\
\text { Low (30\%) }\end{array}$ & $\begin{array}{c}\text { Cluster 3 } \\
\text { Medium (33\%) } \\
\end{array}$ \\
\hline $\begin{array}{l}\text { Electrical Power } \\
\text { Installed: } 450 \text { Volts }\end{array}$ & $\begin{array}{l}\text { Electrical Power } \\
\text { Installed: } 450 \text { Volts }\end{array}$ & $\begin{array}{l}\text { Electrical Power } \\
\text { Installed: } 900 \text { Volts }\end{array}$ \\
\hline $\begin{array}{l}\text { Home Ownership } \\
\text { Status: Own their own } \\
\text { house }\end{array}$ & $\begin{array}{l}\text { Home Ownership } \\
\text { Status: Own their } \\
\text { own house }\end{array}$ & $\begin{array}{l}\text { Home Ownership } \\
\text { Status: Family } \\
\text { owned }\end{array}$ \\
\hline $\begin{array}{l}\text { Age: } 47 \text { years old } \\
\text { Last formal education: } \\
\text { Elementary School }\end{array}$ & $\begin{array}{l}\text { Age: } 44 \text { years old } \\
\text { Last formal } \\
\text { education: Ele- } \\
\text { mentary School }\end{array}$ & $\begin{array}{l}\text { Age: } 30 \text { years old } \\
\text { Last formal } \\
\text { education: High } \\
\text { School }\end{array}$ \\
\hline $\begin{array}{l}\text { Average electricity } \\
\text { expenses: IDR80,424 }\end{array}$ & $\begin{array}{l}\text { Average electricity } \\
\text { expenses: } \\
\text { IDR181,133 }\end{array}$ & $\begin{array}{l}\text { Average electricity } \\
\text { expenses: } \\
\text { IDR232,000 }\end{array}$ \\
\hline $\begin{array}{l}\text { Occupation of the } \\
\text { household head: }\end{array}$ & $\begin{array}{l}\text { Occupation of the } \\
\text { household head: }\end{array}$ & $\begin{array}{l}\text { Occupation of the } \\
\text { household head: }\end{array}$ \\
\hline Farmer & Farmer & Entrepreneur \\
\hline
\end{tabular}

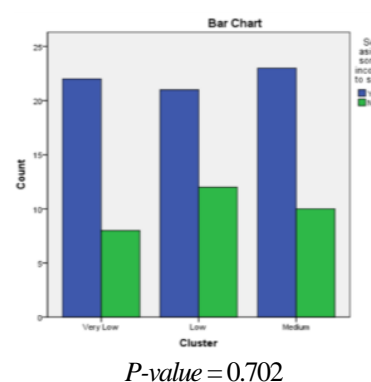

(2a) Set aside some income to save

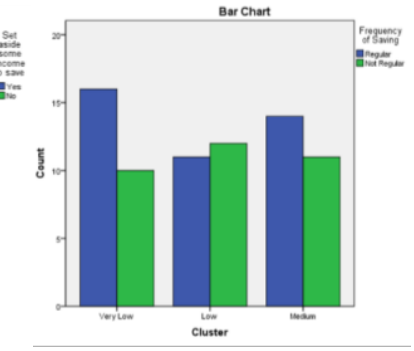

$P$-value $=0.627$

(2b) Frequency of savings

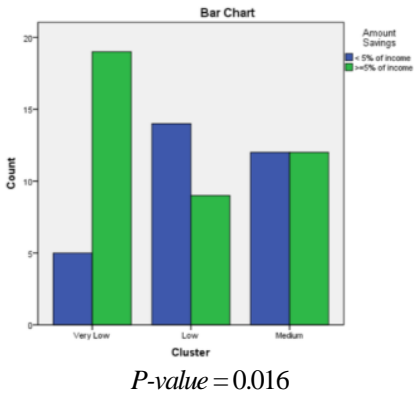

(2c) Amount of Savings

Figure 2. Cross tabulations and chi-squared of savings behavior

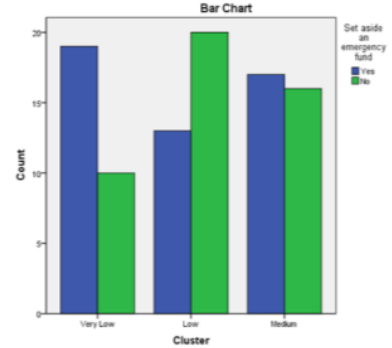

$P$-value $=0.120$

(3a) Precautionary savings

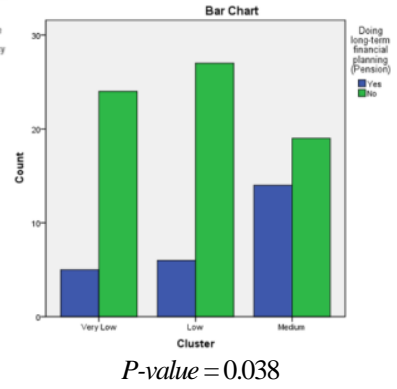

(3b) Long term financial planning
Figure 3. Cross tabulations and chi-squared on precautionary savings and long-term financial planning

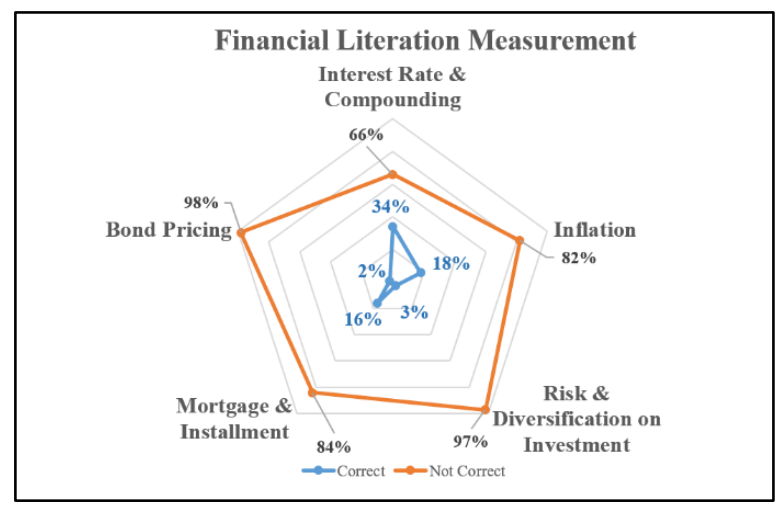

Figure 4. Financial literacy measurement

Figure 5 presents the results of the actual, perceived and bias of the financial knowledge score. The actual knowledge and the perception of financial literacy knowledge of the families is quite low (14\% 
of the maximum score of $100 \%$ ). This indicates that families not only have a low financial literacy, but that they are also quite aware that they have low financial knowledge. Based on the ANOVA test, there is no significant difference between these two values.

The bias of financial literacy, calculated based on the actual and perception of financial literacy knowledge, does not differ among the groups. There is primarily no bias. However, there is a trend in terms of a slight increase of the under confidence gap as the welfare increases. This might be affected by the different characteristics of education that lies between the groups. The medium group has a higher education, so they might have increased their knowledge in literacy, but still feel that they do not understand what is causing the higher under confidence.

To strengthen the results, we categorized the test results into five groups: 1) very low (score: 0 $19.99 \%$ ), 2) low (score: 20\%-39.99\%), 3) medium (score: 40\%-59.99\%), 4) high (score: 60\%-79.99\%), and 5) very high (score: $80 \%-100 \%$ ). The results illustrate that, in general, both the actual financial literacy and the perceived financial literacy scores are included in a very low and low category. The cluster comparison also indicates that there is no difference in trend between the clusters.

Kiliyanni and Sivaraman (2016) found that financial literacy in Kerala (India) is low. They also found that age, education, occupation, and income have an influence on financial literacy. It was also observed that respondents tend to overrate their financial literacy by around $50 \%$, indicating their over -confidence in the knowledge of matters related to personal finance.

Our results differ from that of Kiliyanni and Sivaraman (2016). The nature of financial literacy in the BOP tends to be low. The increase in income, age, education, and the occupation level does not increase their actual financial literacy score. In addition, the BOP people do not tend to have over-confidence in their financial knowledge. This is probably caused by limited information received by the BOP population and a lack of intervention conducted by the financial regulator and the industries.

The distribution of financial services in the BOP areas is still low (KPMG, 2015). This is another factor causing very low and low financial literacy scores. Nevertheless, it is believed that financial literacy, precautionary savings, and retirement planning, are positively correlated. This fact is mostly driven by the perceived literacy.

\section{Preferences}

Figure 6 shows the financial service preferences of the BOP. The top three financial services preferred by the BOP are: (1) Loans from a family (28.3\%), (2)
Savings Clubs (26.8\%), and (3) Banking Services (18.9\%). In general, the majority of the BOP are using non-formal financial services. For a further analysis, we consider simplifying the categories based on the preferences between formal (banking and co-operative), non-formal (family, saving club, friends, etc.) and a combination of formal and non-formal financial services.

When asked about the top two financial service preferences, people mostly choose both non-formal financial service categories as the top two main financial service preferences $(60.67 \%)$. This was followed by the combination of formal and nonformal financial services preferences $(38.20 \%)$. People who prefer to only use formal financial services is very low $(2.6 \%)$. The difference in preferences illustrates the preferences among the clusters. The medium group has a higher tendency of using a combination of formal and non-formal financial services as a preference. The low and very low groups prefer to use non-formal financial services.

The results of the preferences, where people tend to use non-banking financial facilities, are also in line with the experience of using financial banking facilities, where most of the BOP people have no experience in using financial banking services. This condition differs among groups. The low group has the least preference for using financial banking services. This was followed by the very low group and the medium group.

Overall, the better the group's people are, the more they move into formal financial services. This result is in line with the experience of using financial banking services. However, for using financial banking services, there is an interesting condition where the very low clusters show a higher level of experience of being exposed to banking, when compared to the low clusters. This is similar to the savings behavior. The very low group has the lowest income, but is more mature in age and tends to be more disciplined and committed to savings. This will lead to more exposure of using financial banking services.

\section{Financial Literacy and the Relationship to Savings Behavior \& Preferences}

The savings behavior and preference indicators of the BOP are mostly indifferent between the actual, perceived, and bias financial literacy category. Based on the P-values of the Chi-squared tests in Table 2, only the long-term financial planning differs. This is based on the actual and bias financial literacy category, as well as the formal versus non-formal preferences, which differs based on the perceived financial literacy category. 
Table 2

Savings Behavior and Preference Comparisons Based on Literacy

\begin{tabular}{|c|c|c|c|}
\hline \multirow{2}{*}{ Variables } & \multicolumn{3}{|c|}{ Literacy } \\
\hline & Actual & Perceived & Bias \\
\hline \multicolumn{4}{|l|}{ A. Savings behavior: } \\
\hline $\begin{array}{l}\text { Set aside some income to } \\
\text { save }\end{array}$ & 0.373 & 0.770 & 0.907 \\
\hline Frequency of savings & 0.789 & 0.985 & 0.337 \\
\hline Amount of savings & 0.388 & 0.911 & 0.709 \\
\hline Precautionary savings & 0.186 & 0.754 & 0.984 \\
\hline $\begin{array}{l}\text { Long-term financial } \\
\text { planning }\end{array}$ & $0.101 *$ & 0.954 & $0.025^{* * * *}$ \\
\hline \multicolumn{4}{|l|}{ B. Preferences: } \\
\hline $\begin{array}{l}\text { Formal vs. non-formal } \\
\text { preferences }\end{array}$ & 0.647 & $0.008 * * *$ & 0.165 \\
\hline $\begin{array}{l}\text { Experience of using } \\
\text { financial banking facilities }\end{array}$ & 0.822 & 0.237 & 0.320 \\
\hline
\end{tabular}

The first issue to address is the occurrence of the long-term financial planning that differs based on the actual financial literacy category. There is a trend of a negative association. The number of people that do not have long-term financial planning is decreasing when the actual financial literacy increases. Next, when it is based on the biased financial literacy category, the non-biased and overconfidence group are more reluctant in conducting pension plans.

In the under-confidence group, it is balanced between those who have and do not have pension plans. As for the preference of using formal financial services that have a significant association with the perceived literacy category, there is a trend that the higher the perceived literacy, the more people start to use formal banking. The high preference and usage of formal financial services leads to higher financial inclusion.

We have found that the actual and perceived financial literacy of the family and the bias of the financial literacy are low and do not differ across the groups. We have found that there is a slight trend. More specifically, groups with lower economic resources have less engagement with banking facilities. This is the reason for the low perceived literacy rate, which leads to the low utilization of banking facilities mentioned previously.

Financial inclusion requires incremental skills, resources, and needs of the financial facility users. This is accomplished by advancing the step by step active engagement with a growing range of financial services. Perceived financial literacy arises as the financial outcomes increase (Allgood \& Walstad, 2012).

From the facts stated previously, we can see that some aspects related to the demand side of the BOP are associated with BOP groups and the level of BOP literation. This could be a key motivation to conduct in the wider research on BOP groups around Indonesia for broader and more robust results. Therefore, different types of interventions could be well planned and administered for the indicated subgroups to provide a more powerful impact on literacy that would affect the financial behavior and increase preferences to use formal financial services.

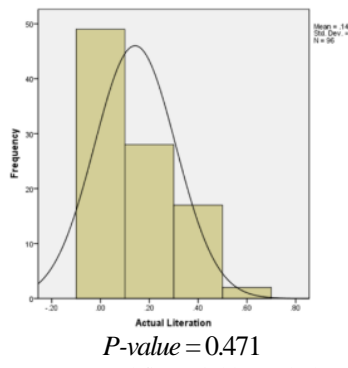

(5a) Actual financial knowledge

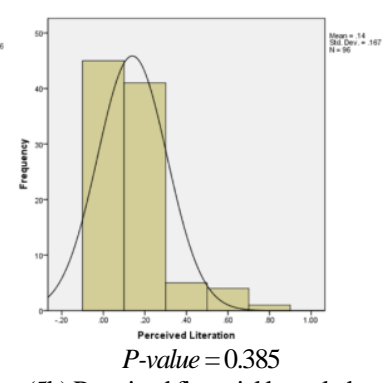

(5b) Perceived financial knowledge

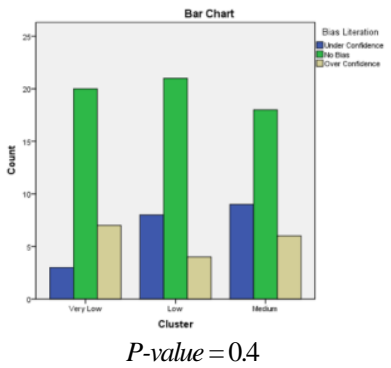

(5c) Bias of financial knowledge

Figure 5. Actual, perceived, and bias of financial literacy

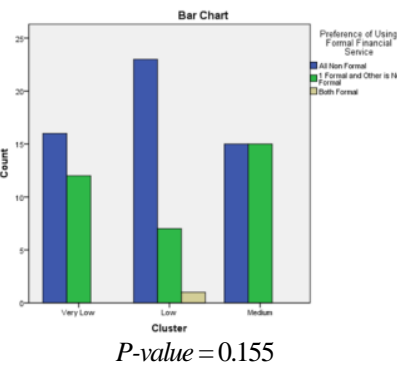

(6a) Top two financial preferences, based on the clusters

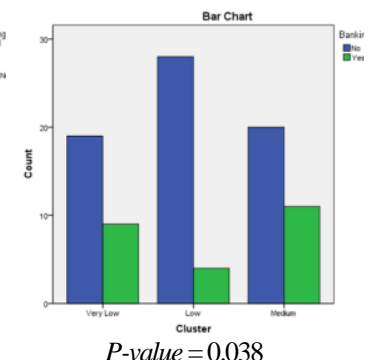

(6b) Experience in using banking financial facilities
Figure 6. Cross tabulation and chi-squared on the preferences and experience of using banking facilities

\section{Conclusions}

This research compares BOP groups in relation to financial behavior, literacy, and preferences. The groups were obtained from a two-step cluster analysis. The demand side of the financial inclusion perspective shows low engagement with the formal financial service provider by the BOP, especially for the most reluctant group. This low engagement causes low perceived literation, which matches the actual literation. This causes people to reluctantly use the 
Table 3

Summary Results

\begin{tabular}{|c|c|c|c|}
\hline Aspects & General Comments & Cluster Comparison & Financial literacy Comparison \\
\hline $\begin{array}{l}\text { Basic savings behavior: } \\
\text { - Set aside some income to } \\
\text { save } \\
\text { - Frequency of savings } \\
\text { - Amount of savings }\end{array}$ & $\begin{array}{l}\text { Financial behavior for basic } \\
\text { activity is quite high. }\end{array}$ & $\begin{array}{l}\text { Significantly different } \\
\text { for the amount of } \\
\text { savings. }\end{array}$ & Not significantly different. \\
\hline $\begin{array}{l}\text { Basic financial planning } \\
\text { attitudes: } \\
\text { - Precautionary } \\
\text { - Long-term financial planning } \\
\text { savings. }\end{array}$ & Financial planning is still low. & $\begin{array}{l}\text { Significantly different } \\
\text { for both indicators. }\end{array}$ & $\begin{array}{l}\text { Significantly different for long- } \\
\text { term financial planning based on } \\
\text { actual and bias literation. }\end{array}$ \\
\hline $\begin{array}{l}\text { Financial literacy: } \\
\text { - Actual. } \\
\text { - Perceived. } \\
\text { - Bias. }\end{array}$ & $\begin{array}{l}\text { Actual and the perception of } \\
\text { financial literacy of the } \\
\text { families are quite low. } \\
\text { No bias. }\end{array}$ & $\begin{array}{l}\text { Not significantly } \\
\text { different. }\end{array}$ & $\begin{array}{l}\text { The actual and perceived financial } \\
\text { literacy level is the same (14\%), } \\
\text { thus no bias regarding financial } \\
\text { knowledge. }\end{array}$ \\
\hline $\begin{array}{l}\text { Preference of financial services: } \\
\text { - Top two preferences. } \\
\text { - Experience of using financial } \\
\text { banking facilities. }\end{array}$ & $\begin{array}{l}\text { People tend to prefer non- } \\
\text { formal financial services. } \\
\text { Most of the BOP people } \\
\text { have no experience in using } \\
\text { financial banking services. }\end{array}$ & $\begin{array}{l}\text { Significantly different } \\
\text { for using financial } \\
\text { banking facilities. }\end{array}$ & $\begin{array}{l}\text { Significantly different for financial } \\
\text { services preference based on } \\
\text { perceived literation. }\end{array}$ \\
\hline
\end{tabular}

formal financial facility, regardless of their high intensity in doing basic financial activities.

Within the financial activities observed in this research, other than the basic financial activity, basic financial planning attitudes are taken into consideration. The results point to a significant difference in the long-term financial planning and precautionary savings. Hence, different types of interventions are needed for the indicated subgroups to have an impact on the literation that would affect the financial behavior and increase the preferences to use formal financial services.

\section{Implications}

There are some recommendations that can be provided to the regulators and financial industry actors. These include: (a). Increase engagement between the BOP and formal financial institution/ products through incremental and different types of interventions for the indicated sub-groups depends on the socio-economic and financial literacy level, (b). Facilitate a financial literacy program based on the cluster characteristics (level of education, occupation, generation, and socio-economic status), and (c). Initiate financial product design (basic \& financial planning) dedicated to the BOP, based on the cluster characteristics.

\section{Future Research}

There are several limitations to this research that should be addressed. First, the sample size selected for the study was small and was concentrated in one area: The Bogor Regency. Therefore, future research should employ a larger sample size and include different geographical areas. Nevertheless, this research can be used as a stepping stone in the development of more focused and specific interventions led by financial regulators and the financial industry.

\section{References}

Allgood, S., \& Walstad, W. B. (2012). The effects of perceived and actual financial literacy on financial behaviors. Economic Inquiry, 54(1), 675697. https://doi.org/1 0.1111/ecin.12255

Anderson, A., Baker, F., \& Robinson, D. T. (2017). Precautionary savings, retirement planning and misperceptions of financial literacy. Journal of Financial Economics, 126(2), 383-398. doi:10. 1016/j.jfineco.20 17.07.008

Anwar, A. I., Uppun, P., \& Reviani, I. T. A. (2016, June). The role of financial inclusion to poverty reduction in Indonesia. IOSR Journal of Business and Management, 18(6/III), 37-39. doi: 10.9790/487X-1806033739

Bank of Indonesia. (n.d.). Keuangan inklusif, apa, mengapa, bagaimana, \& siapa. Retrieved January 28, 2019, from Bank of Indonesia: https://www.bi.go.id/id/perbankan/keuanganinklusif/Indonesia/Contents/Default.aspx

Badan Pusat Statistik (BPS). (2019a, January 4). Jumlah penduduk miskin menurut kabupaten/kota 2015-2018. Retrieved January 25, 2019, from Badan Pusat Statistik: https:/www.bps.go.id/ 
dynamictable/2017/08/03/1260/jumlah-penduduk-miskin-menurut-kabupaten-kota-20152018.html -- (2019b, January 16). Jumlah penduduk miskin menurut provinsi, 2007-2018. Retrieved January 25, 2019, from Badan Pusat Statsistik: https://www.bps.go.id/dynamictable/2016/01/18 /1119/jumlah-penduduk-miskin-menurut-provinsi-2007-2018 .html

Boukhatem, J. (2016). Assessing the direct effect of financial development on poverty reduction in a panel of low-and middle-income countries. Research in International Business and Finance, 37, 214-230. doi:10.1016/j.ribaf.2015.11.008

Brounen, D., Koedijk, K. G., \& Pownall, R. A. (2016). Household financial planning and savings behavior. Journal of International Money and Finance, 69, 95-107. doi:10.1016/j.jimonfin.2016.06.011

Cole, S.A., Sampson, T.A., \& Zia, B.H. (2009). Financial literacy, financial decisions, and the demand for financial services: Evidence from India and Indonesia. Working Paper 09-117. Cambridge, MA: Harvard Business School.

Danella, J., Rahadi, R.A., \& Helmi, I. (2017, December). A conceptual study on the impact of financial literacy level to household wealth in Bandung. Journal of Humanities, Language, Culture and Business (HLCB), 1(6), 82-93. Retrieved January 15, 2019, from http://www. icohlcb.com/images/Articles/vol_1_No.6/Paper099-.pdf.

Demirgüç-Kunt, A., Klapper, L., Singer, D., Ansar, S., \& Hess, J. (2018). The global findex database 2017: Measuring financial inclusion and fintech revolution. Retrieved January 11, 2019, from The World Bank IBRD.IDA: https://globalfindex.worldbank.org/\#data_sec_fo cus.

Diez, D. M, Barr, C. D, \& Cetinkaya-Rundel, M. (2012). Openintro statistics. $2^{\text {nd }}$ edition. South Carolina, USA: CreateSpace Independent Publishing Platform.

Financial Service Authority (OJK). (2013). Indonesian national strategy for financial literacy. Jakarta: OJK. Retrieved May 20, 2018, from https://sikapiuangmu.ojk .go.id/FrontEnd/images/FileDownload/184_OJ K_NATIONAL $\% 20$ STRATEGY\%20FOR\%2 0FINANCIAL\%20LITERACY.pdf.

Grohmann, A., Klühs, T., \& Menkhoff, L. (2018). Does financial literacy improve financial inclusion? Cross country evidence. World Development, 111, 84-96. doi:10.1016/j.worlddev.2018. 06.020
Gross, M. B., Hogarth, J. M., \& Schmeiser, M. D. (2012). Use of financial services by the unbanked and underbanked and the potential for mobile financial services adoption. Federal Reserve Bulletin, 98(4), 1-20.

Hawkins, D. I., \& Mothersbaugh, D. L. (2010). Consumer behaviour: Building marketing strategy (11 ed.). New York: McGraw-Hill, Irwin.

Israel, G. D. (1992). Determining sample size. Florida, USA: University of Florida Cooperative Extension Service, Institute of Food and Agriculture Sciences, EDIS.

Kilara, T., \& Rhyne, E. (2014, June). Research \& analysis publication, customer-centricity for financial inclusion. Retrieved January 28, 2019, from CGAP: https: //www.cgap.org/sites/ default/files/researches/documents/Brief-Customer-Centricity-for-Financial-Inclusion-Jun2014. pdf.

Kiliyanni, A. L., \& Sivaraman, S. (2016). The perception-reality gap in financial literacy: Evidence from the most literate state in India. International Review of Economics Education 23(C), 47-64.

KPMG. (2015). New Indonesian 'branchless banking' and microfinance laws - A catalyst for microfinance growth? Retrieved January 25, 2019, from KPMG Indonesia: http://www. kpmg. com/id.

Lichtenstein, S., \& Slovic, P. (2006). The construction of preference. Oregon, USA: Cambridge University Press. doi: http://dx.doi.org/10.1017 CBO9780511618031

Lind, D. A., Marchal, W. G., \& Wathen, S. A. (2015). Statistical techniques in business and economics. $6^{\text {th }}$ Edition. New York: McGraw-Hill Education.

Lusardi, A. (2010). Americans' financial capability. Report Prepared for the United States Government Financial Crisis Inquiry.

Lusardi, A., \& Mitchell, O. S. (2014). The economic importance of financial literacy: Theory and evidence. Journal of Economic Literature, 52(1), 5-44. doi:http://dx.doi. org/10.1257/jel.52.1.5

Mindra, R., Moya, M., Zuze, L. T., \& Kodongo, O. (2017). Financial self-efficacy: A determinant of financial inclusion. International Journal of Bank Marketing, 35 (3), 338-353. doi: https://doi.org/10.1108/ IJBM-05-2016-0065

Nazer, M., \& Handra, H. (2016). Analisis konsumsi energi rumah tangga perkotaan di Indonesia: Periode Tahun 2008 dan 2011. Jurnal Ekonomi dan Pembangunan Indonesia, 16(2), 141-153. doi:http://dx.doi.org/10.21002/jepi.v16i2.588141 
Niculescu-Aron, I., \& Mihaescu, C. (2012). Determinants of household savings in EU: What policies for increasing savings? Procedia Social and Behavioral Sciences, 58, 483-492.

Nidar, S. R., \& Bestari, S. (2012). Personal financial literacy among university students (Case study at Padjadjaran University students, Bandung, Indonesia). World Journal of Social Sciences, 2(4), 162-171. Retrieved January 15, 2019, from http://wjsspapers.com/static/documents/July/2012/ 13.\%20Sulaeman.pdf.

Otoritas Jasa Keuangan (OJK). (2016). survey nasional literasi dan inklusi keuangan 2016. Retrieved January 25, 2019, from Otoritas Jasa Keuangan: https://sikapiuang mu.ojk.go.id/Front End/CMS/Download/252

Park, C. Y., \& Mercado, Jr., R. V. (2015, January). Financial inclusion, poverty, and income inequality in developing Asia. ADB Economics Working Paper Series No 426. Retrieved January 14, 2019, from https://www.adb.org/ sites/default/files/publication/153143/ewp426.pdf.

Sowunmi, F. A., Omigie, O. C., \& Daniel, D. T. (2014). Consumers' perception on ofada rice in Ibadan North Local Government Area of Oyo State, Nigeria. Journal of Economics and Sustainable Development, 5(16), 78-86.
Statistical Package for the Social Sciences (SPSS). (n.d.). The spss two step cluster component technical report. Retrieved May 20, 2018, from https://www.spss.ch/upload/1122644952_The\% 20SPSS\%20TwoStep\%20Cluster\%20Compone nt.pdf.

Thiyagaraj, V. (2015). Emerging trends in consumer brand preference of herbal hair oil in Tiruppur City. Abhinav International Monthly Refereed Journal of Research in Management \& Technology, 4(5), 17-20.

World Bank. (2012, August). Financial inclusion strategies reference framework. Retrieved March 30, 2018, from www.world bank.org: https://siteresources.worldbank.org/EXTFINAN CIALSECTOR/Resourcs/282884-133962465 3091/87038821339624678024/870385013396 24695396/FIStrategies-ReferenceFrameworkFINALAug 2012.pdf.

(2014). Global financial development report, 2014. Retrieved March, 30, 2018, from www.worldbank.org:http://siteresources.world bank.org/EXTGLOBALFINREPORT/Resourc es/8816096-1361888425203/9062080136492 7957721/GFDR-2014_Complete_Report.pdf. - (2017, September 26). Financial inclusion global initiative (figi). Retrieved May 25, 2018, from www.worldbank.org: http://www.worldbank.org/en/topic/financialinclusion/brief/figi. 